\title{
Comparing best-worst method and full consistency method in a fuzzy environment
}

\author{
Arash Haqbin ${ }^{a^{*}}$
}

${ }^{a}$ Shiraz University, Iran

\begin{tabular}{l}
\hline C H R O N I C L E \\
\hline Article history: \\
Received August 22, 2020 \\
Received in revised format: \\
August 31, 2020 \\
Accepted October 222020 \\
Available online \\
November 15, 2021 \\
\hline Keywords: \\
Multicriteria Decision Making \\
(MCDM) \\
Full Consistency Method \\
(FUCOM) \\
Best-Worst Method (BWM) \\
Fuzzy Set Theory \\
\hline
\end{tabular}

\begin{abstract}
A B S T R A C T
Multicriteria Decision Making (MCDM) is one the most important branches of decision theory. Due to the fact that MCDM methods have the utmost significance in management, scholars try to develop more MCDM methods. Since calculating the weights of criteria is an important step in any MCDM method, increasing the accuracy of weight calculating methods can highly affect these methods. This accuracy can be improved by less pairwise comparison between criteria. To this end, the present study seeks to make a comparison between two new weight calculating techniques, namely BWM and FUCOM in a fuzzy environment using a real-world case study Results of this study shows that FUCOM-F provides more reliable results compared to FBWM since its consistency is less than FBWM by a great amount.
\end{abstract}

\section{Introduction}

C 2022 by the authors; licensee Growing Science, Canada.

Being an inseparable and one of the most fundamental aspects of management, decision-making can highly affect the success of any system. Decision-making can be defined as choosing the most ideal alternative from a set of alternatives (Plous, 1993; Janis \& Mann, 1977). Due to the significance of decision-making, researchers and scholars in the field of management studies tried to develop various quantitative methodologies throughout time in order to facilitate the decisionmaking process while increasing the reliability and accuracy of the decisions simultaneously. Needless to say, all the decisions in the real world are made based on more than one criteria. According to Triantaphyllou (2000), when several criteria are considered the decision-making will be known as Multicriteria Decision Making (MCDM). In a classic MCDM problem, a set of alternatives will be prioritized with respect to several criteria. MCDM gained momentum over the last decades, resulting in the development of numerous quantitative techniques such as AHP (Saaty, 1980), ANP (Saaty, 1999), TOPSIS (Hwang \& Yoon, 1981), VIKOR (Opricovic \& Tzeng, 2004), And PROMETHEE (Olson, 2001). There are also more recently developed techniques including SWARA (Keršuliene et al., 2010), WASPAS (Chakraborty \& Zavadskas, 2014), CoCoSo (Yazdani et al., 2019), and MARCOS (Stević et al., 2020). Moreover, in any MCDM problem, the researcher must determine the weight coefficient of all the criteria regardless of utilized techniques. To this end, various mathematical approaches based on pairwise comparison were proposed. Popular amongst them are the Best-Worst Method (BWM), which is developed by Rezaei (2015), and the Full Consistency Method (FUCOM), proposed by Pamučar et al. (2018). The two mentioned techniques are different in the number required pairwise. The required pairwise comparisons for BWM are $2 n-3$ whereas it is $n-1$ for FUCOM. Noteworthy to mention that the weight coefficients highly influence the results of the decision-making and special attention must be paid to the methods for calculating the weights of each criterion (Pamučar \& Ecer, 2020). Furthermore, According to Pamučar \& Ecer (2020), the accuracy of methods for determining the

* Corresponding author.

E-mail address: haqbin.arash@gmail.com (A. Haqbin)

(C) 2022 by the authors; licensee Growing Science, Canada. doi: $10.5267 /$ dsl.2021.11.002 
weight coefficients is extremely dependent on the number of pairwise comparisons. Consequently, FUCOM must have more accurate and reliable results compare to BWM.

Accordingly, the primary purpose of the present paper is to compare the two above-mentioned techniques in a fuzzy environment through a real-world case study selecting the most ideal recovery measures for tourism small and mediumsized enterprises (SMEs). By providing a comparison, the present paper helps those interested in adopting MCDM methods in choosing more efficient weight calculating methods. Also, the case study provides empirical findings regarding recovery measures of SMEs active in the field of tourism.

The rest of this paper is structured as follows. In the next section, the techniques employed for the analysis are explained. Section 3 provides a real-world case study as well as the results. Then, in section 4 a discussion is provided, and finally, the conclusions are drawn in section 5.

\section{Material and Methods}

\subsection{Fuzzy Set Theory}

Fuzzy set theory is initially proposed by Zadeh (1965) as an extension to classic set theory. fuzzy set theory is a membership function that plots elements to degrees of membership within a specific interval (Commonly [0, 1]). Fuzzy set theory can be extremely practical in uncertain decision-making environments and can eliminate the vagueness, ambiguity, and subjectiveness of the decision-makers (DMs). In the following, the fuzzy set theory and triangular fuzzy numbers (TFNs) are further described:

Definition 1. Assume that $\widetilde{\omega} \in F(R)$ is a fuzzy number if two conditions are met. First, there is $x_{0} \in R$ such that $\mu_{\widetilde{\omega}}\left(x_{0}\right)=$ 1. Second, for any $\alpha \in[0,1], \widetilde{\omega}_{\alpha}=\left[\mathrm{x}, \mu_{\widetilde{\omega}_{\alpha}}(\mathrm{x}) \geq \alpha\right]$ is a closed interval. It should be noted that $\mathrm{R}$ is the set of real numbers and $F(R)$ shows the fuzzy set.

Definition 2. A fuzzy number $\widetilde{\omega}$ on $\mathrm{R}$ is a triangular fuzzy number $(\mathrm{TFN})$ if its member function $\mu_{\widetilde{\omega}_{\alpha}}(\mathrm{x}): R \rightarrow[0,1]$ is:

$$
\mu_{\widetilde{\omega}_{\alpha}}(x)=\left\{\begin{array}{cc}
0, & x<1 \\
\frac{x-1}{m-l}, & l \leq x<m \\
\frac{u-x}{u-m}, & m \leq x \leq u \\
0, & x>u
\end{array}\right.
$$

where $1, \mathrm{~m}$, and $\mathrm{u}$ denote the lower, modal, and upper value of the $\widetilde{\omega}$ in crisp form, respectively. A TFN always is shown as (1, m, u). Also, refer to Carlsson \& Fullér (2001) for basic operations between two TFNs.

Definition 3. The graded mean integration representation (GMIR) of a TFN $\widetilde{\omega}$ shows the ranking of that triangular fuzzy number and can be computed as:

$$
R\left(\widetilde{\omega}_{i}\right)=\frac{l_{i}+4 m_{i}+u_{i}}{6}
$$

\subsection{Fuzzy Best-Worst Method (FBWM)}

Fuzzy BWM was first proposed by Guo and Zhao (2017) and successfully applied in various contexts including supplier selection (Gupta \& Barua, 2017; Ecer \& Pamučar, 2020), healthcare management (Rowshan et al., 2020; Amiri et al., 2020), organizations performance evaluation (Gupta, 2018), and supply chain risk assessment (Khan et al., 2020). According to Guo and Zhao (2017), the steps of Fuzzy BWM are as follows:

Step 1. First, a set of decision criteria will be determined, which are depicted as $\left\{\mathrm{C}_{1}, \mathrm{C}_{2}, \ldots, \mathrm{C}_{\mathrm{n}}\right\}$. Then, the best (most important and most desirable) and worst (least important or least desirable) criteria will be identified. The best criterion is $\mathrm{C}_{\mathrm{B}}$ whereas the worst criterion is $\mathrm{C}_{\mathrm{W}}$.

Step 2. Next, the preference of the best criterion in comparison to other criteria will be determined according to the scale shown in Table 1. The Best-to-Others vector is depicted by:

$$
\widetilde{\mathrm{A}}_{\mathrm{B}}=\left(\mathrm{a}_{\mathrm{B} 1}, \mathrm{a}_{2}, \ldots, \mathrm{a}_{\mathrm{Bn}}\right)
$$


where $a_{B j}$ indicates the preference of the best criterion $B$ over criterion $j$, and: $a_{B B}=(1,1,1)$. Similarly, the preference of the worst criterion compared to other criteria will be determined, and The Others-to-Worst vector is as follows:

$$
\widetilde{\mathrm{A}}_{\mathrm{W}}=\left(\mathrm{a}_{1 \mathrm{~W}}, \mathrm{a}_{2 \mathrm{~W}}, \ldots, \mathrm{a}_{\mathrm{nW}}\right)
$$

where $a_{j w}$ indicates the preference of the criterion $j$ over the worst criterion $W$. Needless to say that: $a_{w w}=(1,1,1)$

Table 1

Fuzzy Linguistic Terms for Decision-makers

\begin{tabular}{ccc}
\hline Linguistic Terms & Membership Function & Consistency Index (FBWM) \\
\hline Equally Important (EI) & $(1,1,1)$ & 3.00 \\
Weakly Important (WI) & $(2 /, 3,13 / 2)$ & 3.80 \\
Fairly Important (FI) & $(3 /, 2,25 / 2)$ & 5.29 \\
Very Important (VI) & $(5 /, 2,37 / 2)$ & 6.69 \\
Absolutely Important (AI) & $(7 /, 2,49 / 2)$ & 8.04
\end{tabular}

Step 3. Then, the optimal weights $\left(\widetilde{\mathrm{w}}_{1}^{*}, \widetilde{\mathrm{w}}_{2}^{*}, \ldots, \widetilde{\mathrm{w}}_{\mathrm{n}}^{*}\right)$ will be found. To calculate the optimal weights of each criterion, the following model must be solved.

$$
\begin{gathered}
\min \max _{j}\left\{\left|\frac{\widetilde{\mathrm{W}}_{B}}{\widetilde{\mathrm{W}}_{j}}-\widetilde{a}_{B_{j}}\right|,\left|\frac{\widetilde{\mathrm{W}}_{j}}{\widetilde{\mathrm{W}}_{\mathrm{w}}}-\widetilde{\mathrm{a}}_{j \mathrm{w}}\right|\right\} \\
\text { s.t. }\left\{\begin{array}{l}
\sum_{j=1}^{\mathrm{n}} \mathrm{R}\left(\widetilde{\mathrm{W}}_{\mathrm{j}}\right)=1 \\
l_{j}^{\mathrm{w}} \leq \mathrm{m}_{j}^{\mathrm{w}} \leq \mathrm{u}_{j}^{\mathrm{w}} \\
l_{j}^{\mathrm{w}} \geq 0 \\
j=1,2, \ldots, \mathrm{n}
\end{array}\right.
\end{gathered}
$$

To solve the above-mentioned model, it can be transformed to the following nonlinearly constrained optimization model, where $\tilde{\varepsilon}$ is also a TFN.

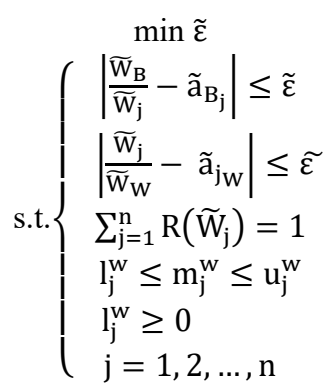

Since $\mathrm{l}^{\varepsilon} \leq \mathrm{m}^{\varepsilon} \leq \mathrm{u}^{\varepsilon}$, it can be assumed that $\tilde{\varepsilon}^{*}=\left(\mathrm{k}^{*}, \mathrm{k}^{*}, \mathrm{k}^{*}\right)$ and $\mathrm{k}^{*} \leq \mathrm{l}^{\varepsilon}$. Thus, the model can also be transformed to:

$$
\begin{aligned}
& \min \tilde{\varepsilon}^{*}
\end{aligned}
$$

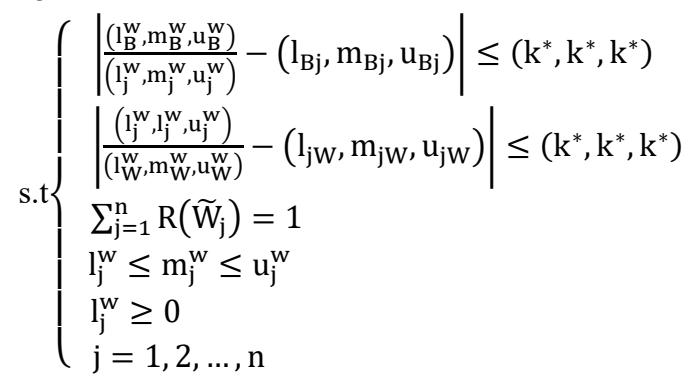

By solving the model in Eq. (7), the optimal weights $\left(\widetilde{\mathrm{w}}_{1}^{*}, \widetilde{\mathrm{w}}_{2}^{*}, \ldots, \widetilde{\mathrm{w}}_{\mathrm{n}}^{*}\right)$ will be determined. 
Step 4. Finally, the consistency of the model must be calculated. Consistency ratio (CR) is a significant index to evaluate the consistency degree of the pairwise comparison using Eq. (8). According to Rezaei (2015), models with a consistency ratio $(\mathrm{CR})$ less than 0.1 are considered consistent.

$$
\mathrm{CR}=\frac{\tilde{\varepsilon}^{*}}{C I}
$$

\subsection{Fuzzy Full Consistency Method (FUCOM-F)}

Pamučar and Ecer (2020) combined the Full Consistency Method with fuzzy set theory to develop FUCOM-F. This recently developed technique is used in several contexts such as transportation management (Pamučar et al., 2020; Mitrović Simić et al., 2020; Pamučar et al., 2021) and healthcare management (Khan et al., 2021). In the following, steps of FUCOM-F are explained:

Step 1. Similar to BWM, a set of decision criteria will be identified, which are represented by $\left\{\mathrm{C}_{1}, \mathrm{C}_{2}, \ldots, \mathrm{C}_{\mathrm{n}}\right\}$. Then, the decision-maker arrange the identified criteria based on their significance in a way that the first criterion is expected to be the most important whereas the last criterion is expected to be the least important

$$
\mathrm{C}_{1} \geq \mathrm{C}_{2} \geq \cdots \geq \mathrm{C}_{\mathrm{n}}
$$

Step 2. Afterward, a pairwise comparison will be done. All the criteria are mutually compared to the most significant criteria using a fuzzy linguistic scale similar to fuzzy BWM (Table 1) to obtain the fuzzy criterion significance $\left(\widetilde{\omega}_{C_{n}}\right)$. Also, because the first-ranked criterion is compared with itself its membership function is $(1,1,1)$. Using the fuzzy criterion significance $\left(\widetilde{\omega}_{C_{n}}\right)$, fuzzy comparative significance $\left(\varphi_{k /(k+1)}\right)$ is computed as follows:

$$
\varphi_{k /(k+1)}=\frac{\widetilde{\omega}_{C_{(k+1)}}}{\widetilde{\omega}_{C_{(k)}}}=\frac{\left(\omega_{C_{(k+1)}}^{l}, \omega_{C_{(k+1)}}^{m}, \omega_{C_{(k+1)}}^{u}\right)}{\left(\omega_{\left.C_{(k)}\right)}^{l}, \omega_{C_{(k)}}^{m}, \omega_{C_{(k)}}^{u}\right)}
$$

Note that $\varphi_{k /(k+1)}$ shows the importance that the criterion of $C_{(k)}$ rank has with respect to the criterion of $C_{(k+1)}$ rank. Finally, a fuzzy vector of the comparative significance of the evaluation criteria is determined as follows:

$$
\vartheta=\left(\varphi_{1 / 2}, \varphi_{2 / 3}, \ldots \varphi_{k / k+1}\right)
$$

Step 3. Next, the fuzzy optimal weights are computed. The final weight values must satisfy two conditions mentioned below:

Condition 1: The ratio of weight coefficients of the criteria should be tantamount to their comparative significance:

$$
\varphi_{k /(k+1)}=\frac{w_{k}}{w_{k+1}}
$$

Condition 2: the final weight values should satisfy transitivity regulation as follows:

$$
\varphi_{k /(k+1)} \otimes \varphi_{(k+1) /(k+2)}=\frac{w_{k}}{w_{k+2}}
$$

According to the two conditions mentioned above, the final nonlinear model for calculating the optimal fuzzy values of the weight coefficients for all criteria is developed as follows:

$$
\text { s.t. }\left\{\begin{array}{c}
\min \tilde{\varepsilon} \\
\left|\frac{\mathrm{w}_{\mathrm{k}}}{w_{k+1}}-\varphi_{\mathrm{k} /(\mathrm{k}+1)}\right| \leq \tilde{\varepsilon} \\
\left|\frac{w_{k}}{w_{k+2}}-\varphi_{k /(k+1)} \otimes \varphi_{(k+1) /(k+2)}\right| \leq \widetilde{\varepsilon} \\
\sum_{\mathrm{j}=1}^{\mathrm{n}} \mathrm{R}\left(\widetilde{\mathrm{W}}_{\mathrm{j}}\right)=1 \\
\mathrm{l}_{\mathrm{j}}^{\mathrm{w}} \leq \mathrm{m}_{\mathrm{j}}^{\mathrm{w}} \leq \mathrm{u}_{\mathrm{j}}^{\mathrm{w}} \\
\mathrm{l}_{\mathrm{j}}^{\mathrm{w}} \geq 0 \\
\mathrm{j}=1,2, \ldots, \mathrm{n}
\end{array}\right.
$$


Similar to fuzzy BWM, the model mentioned in Eq. (14) can be transformed into the model mention in Eq. (7). By solving this model, the optimal weights $\left(\widetilde{\mathrm{w}}_{1}^{*}, \widetilde{\mathrm{w}}_{2}^{*}, \ldots, \widetilde{\mathrm{w}}_{\mathrm{n}}^{*}\right)$ will be computed.

\section{Real World Case Study}

FBWM and FUCOM-F are compared in a real-world problem of selecting the most ideal market-based recovery measure for small and medium-sized enterprises (SMEs) active in the field of tourism. Due to the COVID-19 pandemic started in 2019 (World Health Organization, 2020), the tourism industry has been experiencing tragic years, and, as a result, tourism SMEs had faced severe losses. Obviously, SMEs have encountered major challenges due to the coronavirus, but they still have an alternative to prioritize necessary measures to be able to bounce back as fast as possible. Amongst different measures to help tourism SMEs recover from this pandemic, marketing solutions are considered as one the most significant type of measures (Haqbin et al., 2021). Accordingly, the related literature was reviewed to identify the marketing measures that tourism SMEs can adopt to recover faster from COVID-19. Table 2 shows these possible measures.

Table 4

Marketing Measures for Tourism SMEs recovery from COVID-19

\begin{tabular}{|c|c|c|}
\hline Code & Marketing Measure & References \\
\hline M1 & Digital marketing development & $\begin{array}{c}\text { Pavlatos et al. (2020), Liu et al. (2015), Rodríguez-Antón et al. (2020), } \\
\text { Čorak et al. (2020) }\end{array}$ \\
\hline M2 & Brand image Recovery & $\begin{array}{c}\text { Leung \& Lam (2004), Kim et al. (2005), Gu \& Wall (2006), Beirman } \\
\text { (2006), Johnson Tew et al. (2008), Mao et al. (2010), Fung et al. } \\
\text { (2020), Pavlatos et al. (2020) }\end{array}$ \\
\hline M3 & Marketing campaigns development & $\begin{array}{c}\text { Avraham \& Ketter (2017a), Avraham \& Ketter (2017b), Avraham } \\
\text { (2020), Čorak et al. (2020) }\end{array}$ \\
\hline M4 & Market development strategies & $\begin{array}{c}\text { Gu \& Wall (2006), Johnson Tew et al. (2008), Pavlatos et al. (2020), } \\
\text { Rodríguez-Antón et al. (2020) }\end{array}$ \\
\hline M5 & Guest satisfaction management & Fung et al. (2020), Pavlatos et al. (2020) \\
\hline M6 & $\begin{array}{c}\text { Personalized marketing } \\
\text { development }\end{array}$ & Mao et al. (2010) \\
\hline
\end{tabular}

There are different SMEs with various functions in the tourism industry (Zehrer, 2009) including tourism and travel agencies (TTAs), accommodation service providers, food suppliers, tour operator firms, handicraft suppliers, and car hire agencies. However, according to Imani Khoshkhoo Mohammad \& Nadalipour (2016) TTAs are more important since they manage many tasks, such as selling tickets, offering tour guide services, and advising clients about different traveling-related issues (e.g. making hotel reservations, applying for a visa based on passport information, and registering information for travel insurance. Hence, the identified measures were tested in TTAs. To this end, pairwise comparisons are obtained in a consensus by 5 decision-makers (DMs), who were all experienced senior managers of TTAs in Shiraz, Iran. The data were then analyzed according to FBWM and FUCOM-F. Finally, the weights coefficients of the measures calculated with the techniques are compared with each other.

\subsection{Results: FBWM}

The DMs selected digital marketing development (M1) as the Best criterion and personalized marketing development (M6) as the Worst one. The DMs, then, determined the preference of the best and worst criteria compared to other criteria according to the fuzzy scale mentioned in Table 1, which are represented in Table 3 and Table 4.

Table 3

Linguistic Terms for the Preference of the Best Criterion over all the Criteria

\begin{tabular}{ccccccc}
\hline Criteria & M1 & M2 & M3 & M4 & M5 & M6 \\
\hline Best $=\mathbf{C 1}$ & EI & WI & WI & VI & VI & AI
\end{tabular}

Table 4

Linguistic Terms for the Preference of all the Criteria over the Worst Criterion

\begin{tabular}{cc}
\hline Criteria & Worst $=$ C6 \\
\hline M1 & AI \\
M2 & VI \\
M3 & FI \\
M4 & WI \\
M5 & WI \\
M6 & EI
\end{tabular}


According to the fuzzy preferences, the Best-to-Others vector and the Others-to-Worst vector are as follows:

$\widetilde{\mathrm{A}}_{\mathrm{B}}=((1,1,1),(2 / 3,1,3 / 2),(2 / 3,1,3 / 2),(5 / 2,3,7 / 2),(5 / 2,3,7 / 2),(7 / 2,4,9 / 2))$

$\widetilde{\mathrm{A}}_{\mathrm{W}}=((7 / 2,4,9 / 2),(5 / 2,3,7 / 2),(3 / 2,2,5 / 2),(2 / 3,1,3 / 2),(2 / 3,1,3 / 2),(1,1,1))$

Then, the optimization model can be constructed using the Best-to-Others and the Others-to-Worst vectors according to Eqs. (5) - (7). The optimization model is represented in Appendix. By solving the model in LINGO 18.0 software the fuzzy weights are determined and transformed into crisp weights using the graded mean integration representation (GMIR) mentioned in Eq. (2). Table 5 shows the fuzzy and crisp weights.

Table 5

Fuzzy and Crisp Weights of Measures According to FBWM

\begin{tabular}{ccc}
\hline Marketing Measures & Fuzzy Weights & Crisp Weights \\
\hline M1 & $(0.3073,0.3405,0.3587)$ & 0.3380 \\
M2 & $(0.1616,0.1981,0.2212)$ & 0.1959 \\
M3 & $(0.1616,0.1981,0.2212)$ & 0.1959 \\
M4 & $(0.0850,0.0915,0.0955)$ & 0.0911 \\
M5 & $(0.0850,0.1012,0.1525)$ & 0.1070 \\
M6 & $(0.0687,0.0728,0.0728)$ & 0.0722
\end{tabular}

Ultimately, the consistency of the optimization model is determined. Since $\tilde{a}_{B W}=$ AI; therefore, CI has a value of 8.04 . Also, $\widetilde{\varepsilon}^{*}=0.7191$. According to Eq. (8), the optimization model has a consistency ratio (CR) of 0.0894 . According to Rezaei (2015). CR values less than 0.1 are acceptable and considered consistent.

\subsection{Results: FUCOM-F}

According to the steps of FUCOM-F, DMs also selected digital marketing development (M1) as the most significant recovery measure. DMs put the rest of the marketing measures in the following order:

$$
\mathrm{M} 1>\mathrm{M} 2>\mathrm{M} 3>\mathrm{M} 5>\mathrm{M} 4>\mathrm{M} 6
$$

Afterward, the fuzzy criterion significance $\left(\widetilde{\omega}_{C_{n}}\right)$ determined by DMs using the fuzzy scale in Table 1. Table 6 fuzzy criterion significance is denoted for all the measures.

Table 6

Fuzzy Criterion Significance for the Measures

\begin{tabular}{ccccccc}
\hline Marketing Measures & M11 & M12 & M13 & M15 & M14 & M16 \\
\hline Linguistic term & EI & WI & WI & VI & VI & AI \\
TFN & $(1,1,1)$ & $(2 / 3,1,3 / 2)$ & $(2 / 3,1,3 / 2)$ & $(5 / 2,3,7 / 2)$ & $(5 / 2,3,7 / 2)$ & $(7 / 2,4,9 / 2)$
\end{tabular}

Then, fuzzy comparative significance $\left(\varphi_{k /(k+1)}\right)$ is computed for all the measures as represented in Table 7 .

Table 7

Fuzzy Comparative Significance

\begin{tabular}{cc}
\hline & Fuzzy Comparative Significance \\
\hline$\varphi_{1 / 2}$ & $(0.67,1.00,1.50)$ \\
$\varphi_{2} / 3$ & $(0.45,1.00,2.24)$ \\
$\varphi_{3} / 5$ & $(1.67,3.00,5.22)$ \\
$\varphi_{5} / 4$ & $(0.71,1.00,1.40)$ \\
$\varphi_{4} / 6$ & $(1.00,1.33,1.80)$ \\
$\varphi_{1 / 3}$ & $(0.67,1.00,1.50)$ \\
$\varphi_{2} / 5$ & $(1.67,3.00,5.22)$ \\
$\varphi_{3} / 4$ & $(1.67,3.00,5.22)$ \\
$\varphi_{5} / 6$ & $(1.00,1.33,1.80)$
\end{tabular}

According to Table 7, and, by taking into consideration the two conditions mentioned in Eqs. (12) - (13), an optimization model is developed and solved using LINGO 18.0 software. The model is shown in Appendix (A). Table 8 shows the fuzzy and crisp weights computed by the FUCOM-F technique. 
Table 8

Fuzzy and Crisp Weights of Measures According to FUCOM-F

\begin{tabular}{ccc}
\hline Marketing Measures & Fuzzy Weights & Crisp Weights \\
\hline M1 & $(0.1677,0.2521,0.3733)$ & 0.2582 \\
M2 & $(0.2512,0.2521,0.2521)$ & 0.2519 \\
M3 & $(0.1677,0.2513,0.3733)$ & 0.2577 \\
M4 & $(0.0715,0.0837,0.1003)$ & 0.0844 \\
M5 & $(0.0715,0.0839,0.1003)$ & 0.0846 \\
M6 & $(0.0556,0.0630,0.0713)$ & 0.0631
\end{tabular}

Also, by solving the optimization model, it is determined that $\tilde{\varepsilon}^{*}=0.0028$, which indicates the deviation from the full consistency.

\section{Discussion}

The present study tried to make a comparison between FBWM and FUCOM-F thorough out a case study. Being a fundamental part of the MCDM problems, calculating the weight coefficients of the criteria can be highly affected by the number of pairwise comparisons made by the DMs. Therefore, researchers tried to propose mathematical approaches to reduce the number of these comparisons. In accordance with this issue, the two most novel weight calculating methods namely, BWM and FUCOM were selected to be compared in a fuzzy environment. As mentioned earlier, BWM has $2 n-3$ pairwise comparisons while FUCOM has only $n-1$. Furthermore, a real-world problem of choosing the best market recovery measure for tourism SMEs were proposed to achieve the goal of this study. According to secondary materials obtained from the literature review, 6 main marketing measures were identified that can help tourism SMEs recover faster from the COVID-19 pandemic. These measures include digital marketing development (M1), brand image recovery (M2), marketing campaigns development (M3), market development strategies (M4), guest satisfaction management (M5), and personalized marketing development (M6). 5 DMs expressed their judgments using fuzzy linguistic terms. Noteworthy to mention that fuzzy set theory was adopted in this study to overcome the vagueness and uncertainty of DMs' opinions. Figure 1 illustrates the importance of each measure according to FBWM and FUCOM-F.

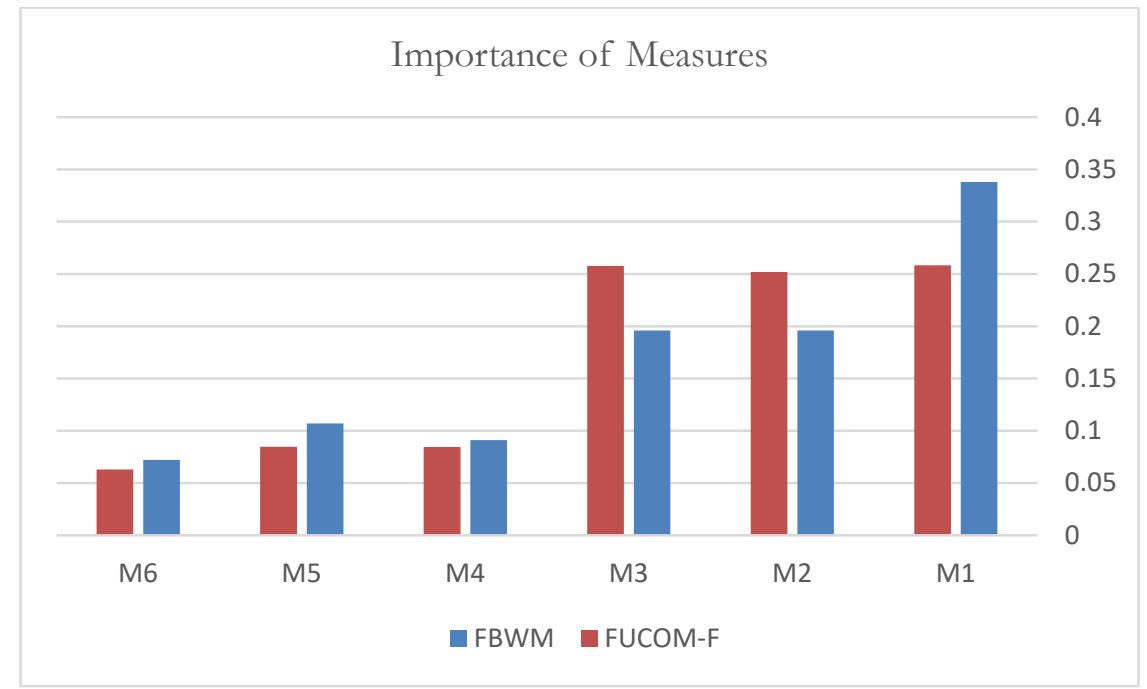

Fig. 1. Weight of each Measure According to FBWM and FUCOM-F

According to Fig. 1, digital marketing development (M1) is considered the most important recovery measure for tourism SMEs based on the two adopted techniques. On the other hand, personalized marketing development (M6) is the least significant according to the techniques as well. Moreover, it should be noted that the disparity amongst the weight coefficients of measures calculated by FBWM is much higher compared to FUCOM-F. After digital marketing development, brand image recovery (M2) and marketing campaigns development (M3) are the most important marketing measures; however, by only a negligible amount according to FUCOM-F. Fig. 2 also represents the comparison of the weight coefficients of measures computed by the two techniques.

The other important factor in comparing FBWM and FUCOM-F is their consistency. Due to the fact that FUCOM-F has fewer pairwise comparisons, its consistency is higher than FBWM. Of course, the findings of both methods are consistent (less than 0.1 ); the consistency of FBWM is 0.0894 whereas FUCOM-F deviates from the maximum consistency by only 0.0028. Nevertheless, FUCOM-F provides more reliable results. 


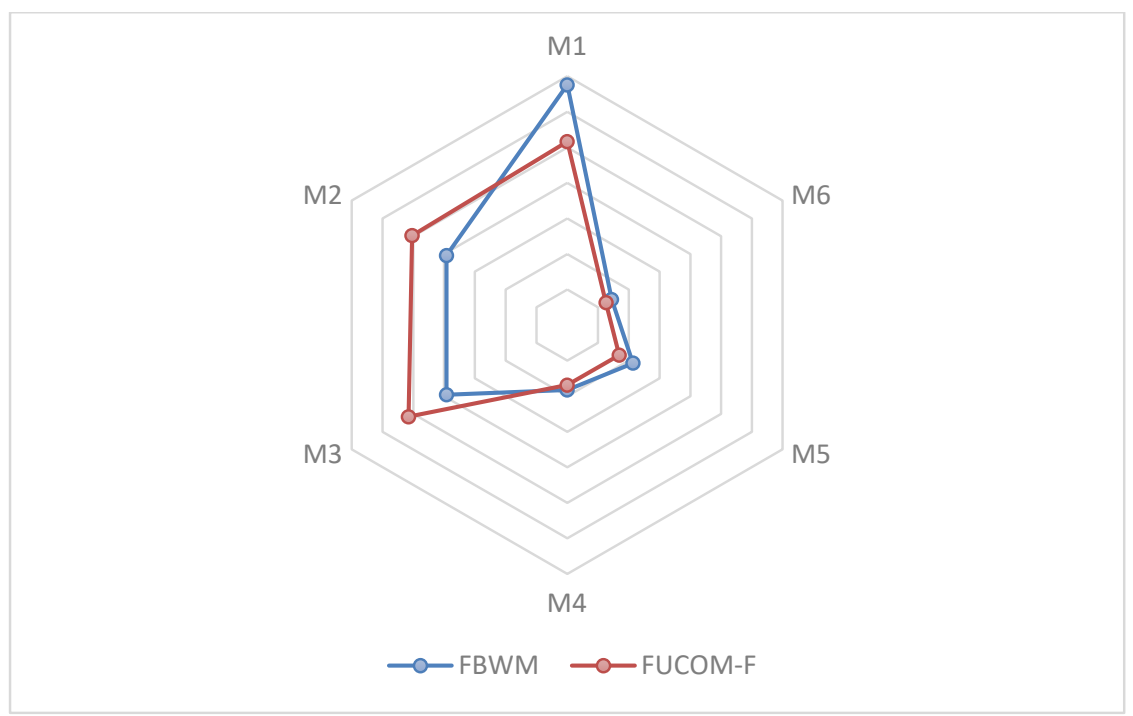

Fig. 2. Weight Values Comparison between FBWM and FUCOM-F

\section{Conclusion}

Multicriteria Decision Making (MCDM) is an integral part of decision-making methods in management since almost all real-world decision-making processes are based on more than one criteria. Because of the importance of MCDM in management, scholars in the field of management sciences seek more reliable and more accurate MCDM methods. Also, calculating the weights of criteria is an important stage in any MCDM method. Hence, increasing the accuracy of weight calculating methods can highly influence the MCDM methods. This accuracy can be achieved by less pairwise comparison between criteria. To this end, the present study tried to make a comparison between the two most novel weight calculating techniques, namely BWM and FUCOM using a case study of selecting the most ideal recovery measure for tourism SMEs in Shiraz, Iran. Moreover, these methods integrated fuzzy set theory to deal with the uncertainty of the judgments, resulting in FBWM and FUCOM-F. The findings of this study show that FUCOM-F provides more reliable results compared to FBWM since its consistency is less than FBWM by a great amount.

\section{Funding}

This research did not receive any specific form of funding.

\section{References}

Amiri, M., Hashemi-Tabatabaei, M., Ghahremanloo, M., Keshavarz-Ghorabaee, M., Zavadskas, E. K., \& Antucheviciene, J. (2020). A new fuzzy approach based on BWM and fuzzy preference programming for hospital performance evaluation: A case study. Applied Soft Computing, 92, 106279. DOI: https://doi.org/10.1016/j.asoc.2020.106279

Avraham, E. (2020). From 9/11 through Katrina to Covid-19: Crisis recovery campaigns for American destinations. Current Issues in Tourism, 1-15. https://doi.org/10.1080/13683500.2020.1849052

Avraham, E., \& Ketter, E. (2017). Destination marketing during and following crises: Combating negative images in Asia. Journal of Travel \& Tourism Marketing, 34(6), 709-718. https://doi.org/10. 1080/10548408.2016.1237926

Avraham, E., \& Ketter, E. (2017a). Destination image repair while combatting crises: Tourism marketing in Africa. Tourism Geographies, 19(5), 780-800. https://doi.org/10.1080/14616688.2017. 1357140

Beirman, D. (2006). A Comparative Assessment of Three Southeast Asian Tourism Recovery Campaigns: Singapore Roars: Post SARS 2003, Bali Post-the October 12, 2002 Bombing, and WOW Philippines 2003. Tourism, Security and Safety, 251-269. DOI: https://doi.org/10.1016/B978-0-7506-7898-8.50021-7

Carlsson, C., \& Fullér, R. (2001). On possibilistic mean value and variance of fuzzy numbers. Fuzzy sets and systems, 122(2), 315-326. DOI: https://doi.org/10.1016/S0165-0114(00)00043-9

Chakraborty, S., \& Zavadskas, E. K. (2014). Applications of WASPAS method in manufacturing decision making. Informatica, 25(1), 1-20. URL: https://content.iospress.com/articles/informatica/inf25-1-01

Čorak, S., Boranić Živoder, S., \& Marušić, Z. (2020). Opportunities for tourism recovery and development during and after COVID-19: Views of tourism scholars versus tourism practitioners. Tourism: An International Interdisciplinary Journal, 68(4), 434-449. DOI: https://doi.org/10.37741/t.68.4.5 
Ecer, F., \& Pamučar, D. (2020). Sustainable supplier selection: A novel integrated fuzzy best worst method (F-BWM) and fuzzy CoCoSo with Bonferroni (CoCoSo'B) multi-criteria model. Journal of Cleaner Production, 266, 121981. DOI: https://doi.org/10.1016/j.jclepro.2020.121981

Fung, C., Tsui, B., \& Hon, A.H. (2020). Crisis management: A case study of disease outbreak in the Metropark Hotel group. Asia Pacific Journal of Tourism Research, 25(10), 1062-1070. DOI: https://doi.org/10.1080/10941665.2020.1784245

Gu, H., \& Wall, G. (2006). SARS in China: Tourism impacts and market rejuvenation. Tourism Analysis, 11(6), $367-379$. URL: https://hrcak.srce.hr/161473

Guo, S., \& Zhao, H. (2017). Fuzzy best-worst multi-criteria decision-making method and its applications. Knowledge-Based Systems, 121, 23-31. DOI: https://doi.org/10.1016/j.knosys.2017.01.010

Gupta, H. (2018). Assessing organizations performance on the basis of GHRM practices using BWM and Fuzzy TOPSIS. Journal of Environmental Management, 226, 201-216. DOI: https://doi.org/10.1016/j.jenvman.2018.08.005

Gupta, H., \& Barua, M. K. (2017). Supplier selection among SMEs on the basis of their green innovation ability using BWM and fuzzy TOPSIS. Journal of Cleaner Production, 152, 242-258. DOI: https://doi.org/10.1016/j.jclepro.2017.03.125

Haqbin, A., Shojaei, P., \& Radmanesh, S. (2021). Prioritising COVID-19 Recovery Solutions for Tourism Small and Medium-sized Enterprises: A Rough Best-Worst method Approach. Journal of Decision Systems, 1-14. DOI: https://doi.org/10.1080/12460125.2021.1927487

Hwang, C. L., \& Yoon, K. (1981). Methods for multiple attribute decision making. In Multiple attribute decision making (pp. 58-191). Springer, Berlin, Heidelberg.

Janis, I. L., \& Mann, L. (1977). Decision making: A psychological analysis of conflict, choice, and commitment. Free press.

Johnson Tew, P., Lu, Z., Tolomiczenko, G., Gellatly, J., \& Jayawardena, C. (2008). SARS: Lessons in strategic planning for hoteliers and destination marketers. International Journal of Contemporary Hospitality Management, 20(3), 332346. DOI: https://doi.org/10.1108/09596110810866145

Keršuliene, V., Zavadskas, E. K., \& Turskis, Z. (2010). Selection of rational dispute resolution method by applying new step-wise weight assessment ratio analysis (SWARA). Journal of business economics and management, 11(2), $243-258$. DOI: https://doi.org/10.3846/jbem.2010.12

Khan, F., Ali, Y., \& Pamucar, D. (2021). A new fuzzy FUCOM-QFD approach for evaluating strategies to enhance the resilience of the healthcare sector to combat the COVID-19 pandemic. Kybernetes. DOI: https://doi.org/10.1108/K-022021-0130

Khan, S., Haleem, A., \& Khan, M. I. (2021, January). Assessment of risk in the management of Halal supply chain using fuzzy BWM method. In Supply Chain Forum: An International Journal (Vol. 22, No. 1, pp. 57-73). Taylor \& Francis. DOI: https://doi.org/10.1080/16258312.2020.1788905

Kim, S.S., Chun, H., \& Lee, H. (2005). The effects of SARS on the Korean hotel industry and measures to overcome the crisis: A case study of six Korean five-star hotels. Asia Pacific Journal of Tourism Research, 10(4), 369-377. DOI: https://doi.org/10.1080/10941660500363694

Leung, P., \& Lam, T. (2004). Crisis Management During the SARS Threat. Journal of Human Resources in Hospitality \& Tourism, 3(1), 47-57. DOI: https://doi.org/10.1300/J171v03n01_05

Liu, B., Pennington-Gray, L., \& Klemmer, L. (2015). Using social media in hotel crisis management: The case of bed bugs. Journal of Hospitality and Tourism Technology, 6(2), 113-126. DOI: https://doi.org/10.1108/JHTT-08-2014-0036

Mao, C.-K., Ding, C.G., \& Lee, H.-Y. (2010). Post-SARS tourist arrival recovery patterns: An analysis based on a catastrophe theory. Tourism Management, 31(6), 855-861. DOI: https://doi.org/10.1016/j. tourman.2009.09.003

Mitrović Simić, J., Stević, Ž., Zavadskas, E. K., Bogdanović, V., Subotić, M., \& Mardani, A. (2020). A novel CRITICFuzzy FUCOM-DEA-Fuzzy MARCOS model for safety evaluation of road sections based on geometric parameters of road. Symmetry, 12(12), 2006. DOI: https://doi.org/10.3390/sym12122006

Mohammad, H., I.K., \& Nadalipour, Z. (2016). Tourism SMEs and organizational learning in a competitive environment: A longitudinal research on organizational learning in travel and tourism agencies located in the city of Ahvaz, Iran. The Learning Organization, 23(2/3), 184-200. DOI: https://doi.org/10.1108/TLO-07-2015-0043

Olson, D. L. (2001). Comparison of three multicriteria methods to predict known outcomes. European Journal of Operational Research, 130(3), 576-587. DOI: https://doi.org/10.1016/S0377-2217(99)00416-6

Opricovic, S., \& Tzeng, G. H. (2004). Compromise solution by MCDM methods: A comparative analysis of VIKOR and TOPSIS. European journal of operational research, 156(2), 445-455. DOI: https://doi.org/10.1016/S03772217(03)00020-1

Pamucar, D., Deveci, M., Canitez, F., \& Bozanic, D. (2020). A fuzzy Full Consistency Method-Dombi-Bonferroni model for prioritizing transportation demand management measures. Applied Soft Computing, 87, 105952. DOI: https://doi.org/10.1016/j.asoc.2019.105952

Pamucar, D., Ecer, F., \& Deveci, M. (2021). Assessment of alternative fuel vehicles for sustainable road transportation of United States using integrated fuzzy FUCOM and neutrosophic fuzzy MARCOS methodology. Science of The Total Environment, 788, 147763. DOI: https://doi.org/10.1016/i.scitotenv.2021.147763

Pamučar, D., Stević, Ž., \& Sremac, S. (2018). A new model for determining weight coefficients of criteria in mcdm models: Full consistency method (fucom). Symmetry, 10(9), 393. DOI: https://doi.org/10.3390/sym10090393

Pavlatos, O., Kostakis, H., \& Digkas, D. (2020). Crisis management in the Greek hotel industry in response to COVID-19 pandemic. Anatolia, 32(1), 1-13. DOI: https://doi.org/10.1080/13032917.2020. 1850485 
Plous, S. (1993). The psychology of judgment and decision making. McGraw-Hill Book Company.

Rezaei, J. (2015). Best-worst multi-criteria decision-making method. Omega, 53, 49-57. DOI: https://doi.org/10.1016/j.omega.2014.11.009

Rodríguez-Antón, J.M., \& Alonso-Almeida, M.D.M. (2020). COVID-19 Impacts and Recovery Strategies: The Case of the Hospitality Industry in Spain. Sustainability, 12(20), 8599. DOI: https://doi.org/10.3390/su12208599

Rowshan, M., Shojaei, P., Askarifar, K., \& Rahimi, H. (2020). Identifying and Prioritizing Effective Factors on Outsourcing in Public Hospitals Using Fuzzy BWM. Hospital topics, 98(1), 16-25. DOI: https://doi.org/10.1080/00185868.2019.1711482

Saaty, T. L. (1999). Fundamentals of the analytic network process. The International Symposium on the Analytic Hierarchy Process, Kobe, Japan.

Saaty, T.L.. (1980). The Analytical Hierarchy Process. McGraw-Hill, New York, NY.

Stević, Ž., Pamučar, D., Puška, A., \& Chatterjee, P. (2020). Sustainable supplier selection in healthcare industries using a new MCDM method: Measurement of alternatives and ranking according to COmpromise solution (MARCOS). Computers \& Industrial Engineering, 140, 106231. DOI: https://doi.org/10.1016/j.cie.2019.106231

Triantaphyllou, E. (2000). Multi-criteria decision making methods. In Multi-criteria decision making methods: A comparative study (pp. 5-21). Springer, Boston, MA.

Yazdani, M., Zarate, P., Zavadskas, E. K., \& Turskis, Z. (2019). A Combined Compromise Solution (CoCoSo) method for multi-criteria decision-making problems. Management Decision. DOI: https://doi.org/10.1108/MD-05-2017-0458

Zadeh, L. A. (1965). Fuzzy sets. Information and Control, 8(2), 338-353.

\section{Appendix}

In the following, the optimization models for FBWM and FUCOM-F in LINGO 18.0 software are presented, respectively:

\section{FBWM:}

model:

$\min =\mathrm{k}$;

$11-0.67 * \mathrm{u} 2<=\mathrm{k} * \mathrm{u} 2 ; 11-0.67 * \mathrm{u} 2>=\mathrm{k} * \mathrm{u} 2 ;$

$\mathrm{m} 1-1 * \mathrm{~m} 2<=\mathrm{k} * \mathrm{~m} 2 ; \mathrm{m} 1-1 * \mathrm{~m} 2>=\mathrm{k} * \mathrm{~m} 2 ;$

u $1-1.5 * 12<=\mathrm{k}^{*} 12 ; \mathrm{u} 1-1.5 * 12>=\mathrm{k} * 12$;

$11-0.67 * \mathrm{u} 3<=\mathrm{k} * \mathrm{u} 3 ; 11-0.67 * \mathrm{u} 3>=\mathrm{k} * \mathrm{u} 3$;

$\mathrm{m} 1-1 * \mathrm{~m} 3<=\mathrm{k} * \mathrm{~m} 3 ; \mathrm{m} 1-1 * \mathrm{~m} 3>=\mathrm{k} * \mathrm{~m} 3$;

$\mathrm{u} 1-1.5 * 13<=\mathrm{k}^{*} 13 ; \mathrm{u} 1-1.5 * 13>=\mathrm{k} * 13$;

$11-2.5^{*} \mathrm{u} 4<=\mathrm{k}^{*} \mathrm{u} 4 ; 11-2.5^{*} \mathrm{u} 4>=\mathrm{k}^{*} \mathrm{u} 4$;

$\mathrm{m} 1-3 * \mathrm{~m} 4<=\mathrm{k} * \mathrm{~m} 4 ; \mathrm{m} 1-3 * \mathrm{~m} 4>=\mathrm{k} * \mathrm{~m} 4$;

$\mathrm{u} 1-3.5 * 14<=\mathrm{k} * 14 ; \mathrm{u} 1-3.5 * 14>=\mathrm{k} * 14$;

$11-2.5^{*} \mathrm{u} 5<=\mathrm{k} * \mathrm{u} 5 ; 11-2.5^{*} \mathrm{u} 5>=\mathrm{k} * \mathrm{u} 5$;

$\mathrm{m} 1-3 * \mathrm{~m} 5<=\mathrm{k} * \mathrm{~m} 5 ; \mathrm{m} 1-3 * \mathrm{~m} 5>=\mathrm{k} * \mathrm{~m} 5$;

u $1-3.5 * 15<=\mathrm{k} * 15 ; \mathrm{u} 1-3.5 * 15>=\mathrm{k} * 15$;

$11-3.5 * \mathrm{u} 6<=\mathrm{k} * \mathrm{u} 6 ; 11-3.5 * \mathrm{u} 6>=\mathrm{k} * \mathrm{u} 6$;

$\mathrm{m} 1-4 * \mathrm{~m} 6<=\mathrm{k} * \mathrm{~m} 6 ; \mathrm{m} 1-4 * \mathrm{~m} 6>=\mathrm{k} * \mathrm{~m} 6$;

u $1-4.5 * 16<=\mathrm{k}^{*} 16 ; \mathrm{u} 1-4.5 * 16>=\mathrm{k} * 16$;

$12-2.5 * \mathrm{u} 6<=\mathrm{k} * \mathrm{u} 6 ; 12-2.5 * \mathrm{u} 6>=\mathrm{k} * \mathrm{u} 6$;

$\mathrm{m} 2-3 * \mathrm{~m} 6<=\mathrm{k} * \mathrm{~m} 6 ; \mathrm{m} 2-3 * \mathrm{~m} 6>=\mathrm{k} * \mathrm{~m} 6$;

$\mathrm{u} 2-3.5 * 16<=\mathrm{k} * 16 ; \mathrm{u} 2-3.5 * 16>=\mathrm{k} * 16$;

$13-1.5^{*} \mathrm{u} 6<=\mathrm{k} * \mathrm{u} 6 ; 13-1.5^{*} \mathrm{u} 6>=\mathrm{k} * \mathrm{u} 6$;

$\mathrm{m} 3-2 * \mathrm{~m} 6<=\mathrm{k} * \mathrm{~m} 6 ; \mathrm{m} 3-2 * \mathrm{~m} 6>=\mathrm{k} * \mathrm{~m} 6$;

u3-2.5*16<=k*16; u3-2.5*16>=k*16;

$14-0.67 * \mathrm{u} 6<=\mathrm{k} * \mathrm{u} 6 ; 14-1 * \mathrm{u} 6>=\mathrm{k} * \mathrm{u} 6$;

$\mathrm{m} 4-1 * \mathrm{~m} 6<=\mathrm{k} * \mathrm{~m} 6 ; \mathrm{m} 4-0.67 * \mathrm{~m} 6>=\mathrm{k} * \mathrm{~m} 6$;

$\mathrm{u} 4-1.5 * 16<=\mathrm{k} * 16 ; \mathrm{u} 4-1.5 * 16>=\mathrm{k} * 16$;

$15-0.67 * \mathrm{u} 6<=\mathrm{k} * \mathrm{u} 6 ; 15-1 * \mathrm{u} 6>=\mathrm{k} * \mathrm{u} 6$;

$\mathrm{m} 5-1 * \mathrm{~m} 6<=\mathrm{k} * \mathrm{~m} 6 ; \mathrm{m} 5-0.67 * \mathrm{~m} 6>=\mathrm{k} * \mathrm{~m} 6$;

$\mathrm{u} 5-1.5 * 16<=\mathrm{k} * 16 ; \mathrm{u} 5-1.5 * 16>=\mathrm{k} * 16$;

$1 / 6 *(11+4 * \mathrm{~m} 1+\mathrm{u} 1+12+4 * \mathrm{~m} 2+\mathrm{u} 2+13+4 * \mathrm{~m} 3+\mathrm{u} 3+14+4 * \mathrm{~m} 4+\mathrm{u} 4+15+4 * \mathrm{~m} 5+\mathrm{u} 5+16+4 * \mathrm{~m} 6+\mathrm{u} 6)=1$;

$11<=\mathrm{m} 1 ; \mathrm{m} 1<=\mathrm{u} 1$;

$12<=\mathrm{m} 2 ; \mathrm{m} 2<=\mathrm{u} 2$;

$13<=\mathrm{m} 3 ; \mathrm{m} 3<=\mathrm{u} 3$;

$14<=\mathrm{m} 4 ; \mathrm{m} 4<=\mathrm{u} 4$;

$15<=\mathrm{m} 5 ; \mathrm{m} 5<=\mathrm{u} 5$;

$16<=\mathrm{m} 6 ; \mathrm{m} 6<=\mathrm{u} 6$;

$11>0 ; 12>0 ; 13>0 ; 14>0 ; 15>0 ; 16>0$; 
$\mathrm{k}>=0$;

end model

\section{FUCOM-F}

model:

$\min =\mathrm{k}$;

$11-0.67 * \mathrm{u} 2<=\mathrm{k} * \mathrm{u} 2 ; 11-0.67 * \mathrm{u} 2>=\mathrm{k} * \mathrm{u} 2$; $\mathrm{m} 1-1 * \mathrm{~m} 2<=\mathrm{k} * \mathrm{~m} 2 ; \mathrm{m} 1-1 * \mathrm{~m} 2>=\mathrm{k} * \mathrm{~m} 2$; $\mathrm{u} 1-1.5 * 12<=\mathrm{k} * 12 ; \mathrm{u} 1-1.5 * 12>=\mathrm{k} * 12$;

$12-0.45^{*} \mathrm{u} 3<=\mathrm{k}^{*} \mathrm{u} 3 ; 12-0.45^{*} \mathrm{u} 3>=\mathrm{k} * \mathrm{u} 3$; $\mathrm{m} 2-1 * \mathrm{~m} 3<=\mathrm{k} * \mathrm{~m} 3 ; \mathrm{m} 2-1 * \mathrm{~m} 3>=\mathrm{k} * \mathrm{~m} 3$; $\mathrm{u} 2-2.24 * 13<=\mathrm{k} * 13 ; \mathrm{u} 2-2.24 * 13>=\mathrm{k} * 13$; $13-1.67 * \mathrm{u} 5<=\mathrm{k} * \mathrm{u} 5 ; 13-1.67 * \mathrm{u} 5>=\mathrm{k} * \mathrm{u} 5$; $\mathrm{m} 3-3 * \mathrm{~m} 5<=\mathrm{k} * \mathrm{~m} 5 ; \mathrm{m} 3-3 * \mathrm{~m} 5>=\mathrm{k} * \mathrm{~m} 5$; u3-5.22*15<=k*15; u3-5.22*15 $>=\mathrm{k} * 15$; $15-0.71 * \mathrm{u} 4<=\mathrm{k} * \mathrm{u} 4 ; 15-0.71 * \mathrm{u} 4>=\mathrm{k} * \mathrm{u} 4$; $\mathrm{m} 5-1 * \mathrm{~m} 4<=\mathrm{k} * \mathrm{~m} 4 ; \mathrm{m} 5-1 * \mathrm{~m} 4>=\mathrm{k} * \mathrm{~m} 4$; u5-1.40*14<=k*14; u5-1.40*14>=k*14; $14-1 * \mathrm{u} 6<=\mathrm{k} * \mathrm{u} 4 ; 14-1 * \mathrm{u} 6>=\mathrm{k} * \mathrm{u} 6$; $\mathrm{m} 4-1.33 * \mathrm{~m} 6<=\mathrm{k} * \mathrm{~m} 4 ; \mathrm{m} 4-1.33 * \mathrm{~m} 6>=\mathrm{k} * \mathrm{~m} 6$; $\mathrm{u} 4-1.80 * 16<=\mathrm{k} * 14 ; \mathrm{u} 4-1.80 * 16>=\mathrm{k} * 16$; $11-0.67 * \mathrm{u} 3<=\mathrm{k} * \mathrm{u} 3 ; 11-0.67 * \mathrm{u} 3>=\mathrm{k} * \mathrm{u} 3$; $\mathrm{m} 1-1 * \mathrm{~m} 3<=\mathrm{k} * \mathrm{~m} 3 ; \mathrm{m} 1-1 * \mathrm{~m} 3>=\mathrm{k} * \mathrm{~m} 3$; $\mathrm{u} 1-1.50 * 13<=\mathrm{k} * 13 ; \mathrm{u} 1-1.50 * 13>=\mathrm{k} * 13$; $12-1.67 * \mathrm{u} 5<=\mathrm{k} * \mathrm{u} 5 ; 12-1.67 * \mathrm{u} 5>=\mathrm{k} * \mathrm{u} 5$; $\mathrm{m} 2-3 * \mathrm{~m} 5<=\mathrm{k} * \mathrm{~m} 5 ; \mathrm{m} 2-3 * \mathrm{~m} 5>=\mathrm{k} * \mathrm{~m} 5$; $\mathrm{u} 2-5.22 * 15<=\mathrm{k} * 15 ; \mathrm{u} 2-5.22 * 15>=\mathrm{k} * 15$; $13-1.67 * \mathrm{u} 4<=\mathrm{k} * \mathrm{u} 4 ; 13-1.67 * \mathrm{u} 4>=\mathrm{k} * \mathrm{u} 4$; $\mathrm{m} 3-3 * \mathrm{~m} 4<=\mathrm{k} * \mathrm{~m} 4 ; \mathrm{m} 3-3 * \mathrm{~m} 4>=\mathrm{k} * \mathrm{~m} 4$; u3-5.22*14<=k*14; u3-5.22*14>=k*14; $15-1 * \mathrm{u} 6<=\mathrm{k} * \mathrm{u} 6 ; 15-1 * \mathrm{u} 6>=\mathrm{k} * \mathrm{u} 6$; $\mathrm{m} 5-1.33 * \mathrm{~m} 6<=\mathrm{k} * \mathrm{~m} 6 ; \mathrm{m} 5-1.33 * \mathrm{~m} 6>=\mathrm{k} * \mathrm{~m} 6$; $\mathrm{u} 5-1.80 * 16<=\mathrm{k} * 16 ; \mathrm{u} 5-1.80 * 16>=\mathrm{k} * 16$;

$1 / 6 *(11+4 * \mathrm{~m} 1+\mathrm{u} 1+12+4 * \mathrm{~m} 2+\mathrm{u} 2+13+4 * \mathrm{~m} 3+\mathrm{u} 3+14+4 * \mathrm{~m} 4+\mathrm{u} 4+15+4 * \mathrm{~m} 5+\mathrm{u} 5+16+4 * \mathrm{~m} 6+\mathrm{u} 6)=1$; $11<=\mathrm{m} 1 ; \mathrm{m} 1<=\mathrm{u} 1$;

$12<=\mathrm{m} 2 ; \mathrm{m} 2<=\mathrm{u} 2$;

$13<=\mathrm{m} 3 ; \mathrm{m} 3<=\mathrm{u} 3$;

$14<=\mathrm{m} 4 ; \mathrm{m} 4<=\mathrm{u} 4$;

$15<=\mathrm{m} 5 ; \mathrm{m} 5<=\mathrm{u} 5$;

$16<=\mathrm{m} 6 ; \mathrm{m} 6<=\mathrm{u} 6$;

$11>0 ; 12>0 ; 13>0 ; 14>0 ; 15>0 ; 16>0$; $\mathrm{k}>=0$;

end model 
(c) $\stackrel{1}{\mathrm{E}}$
(C) 2022 by the authors; licensee Growing Science, Canada. This is an open access article distributed under the terms and conditions of the Creative Commons Attribution (CC-BY) license (http://creativecommons.org/licenses/by/4.0/). 